$10-11-2010$

\title{
The Supreme Court and the Pledge of Allegiance: a Hollow Victory
}

Charles J. Russo

University of Dayton

Ralph D. Mawdsley

Cleveland State University, r.mawdsley@csuohio.edu

Follow this and additional works at: https://engagedscholarship.csuohio.edu/edcasal_facpub

Part of the Educational Administration and Supervision Commons, and the Education Law Commons How does access to this work benefit you? Let us know!

\section{Publisher's Statement}

This is an electronic version of an article published in Russo, C., \& Mawdsley, R. (2004). The Supreme Court and the pledge of allegiance: a hollow victory. Education \& The Law, 16(4), 261-267. Education \& The Law is available online at: http://www.tandfonline.com/ openurl?genre=article\&issn=0953-9964\&volume=16\&issue=4\&spage=261

\section{Original Citation}

Russo, C., \& Mawdsley, R. (2004). The Supreme Court and the pledge of allegiance: a hollow victory. Education \& The Law, 16(4), 261-267.

\section{Repository Citation}

Russo, Charles J. and Mawdsley, Ralph D., "The Supreme Court and the Pledge of Allegiance: a Hollow Victory" (2010). CASAL Faculty Publications. 1.

https://engagedscholarship.csuohio.edu/edcasal_facpub/1

This Article is brought to you for free and open access by the Counseling, Administration, Supervision and Adult Learning Department at EngagedScholarship@CSU. It has been accepted for inclusion in CASAL Faculty Publications by an authorized administrator of EngagedScholarship@CSU. For more information, please contact library.es@csuohio.edu. 


\section{THE SUPREME COURT AND THE PLEDGE OF ALLEGIANGE: A HOLLOVN VIOTORY}

Charles J- Russo, University of Dayton, Obio Ralph D. Mamdsley, Cleveland State University, Obio

In Elk Grove Unified School District v Newdow (EIkGrove), the Supreme Court, in an 8-o judgment, 2 with three concurremces, upheld the words 'under God' in the Pledge of Allegiance. In light of the mproar caused by Elk Grove, this article is divided into three parts. After reviewing the history of the Pledge the second section examnines the litigation involving the pledge, including Elk Grove in this regard. The article concludes with brief reflections on the meaning of Elk Grove.

History of the Pledge of Allegiance

The Pledge of Allegiance (the Pledge), not including the words 'under God,' was written in 1892 by Francis Bellamy, a Baptist minister, who was forced to leave his pulpit due to his socialist leanings. ${ }^{3}$ About a month after the Pledge appeared in The Youth's Companion, a popular magazine for children, on 8 September 1892, public school students recited it to celebrate the 400th anniversary of Columbus' discovery of America. ${ }^{4}$

In 1898, the day after the US declared war on Spain, the New York State legislature passed the first statute requiring students to recite the Pledge. ${ }^{5}$ Rhode Island in 1901 , Arizona in 1903, Kansas in 1917 and Maryland in 1918 enacted similar laws. ${ }^{6}$ Washington state passed the first law directing teachers, under the risk of dismissal, to lead weekly flag exercises; Delaware in 1925, New Jersey in 1932 and Massachusetts in 1935 adopted similar statutes. ${ }^{7}$ By 1940, at least 18 states had laws mandating teaching about the flag while 30 called for some form of reverence for the Pledge and flag salute. ${ }^{8}$

Following the states, in 1942 Congress sought to 'codify and emphasize existing rules and customs pertaining to the display and use of the flag of the US. ${ }^{\text {'9 }}$ Stopping short of mandating its recitation, this codified the Pledge's approved wording. ${ }^{10}$ Later, acting in response to a campaign by the Knights of Columbus, a Roman Catholic fraternal and charitable organization, and other religious groups, all of whom

${ }^{\star}$ Corresponding author. School of Education, University of Dayton, OH 45469-0534, USA. Email: charles_i_russo@hotmail.com 
were motivated by Cold War era fears of communism, ${ }^{11}$ President Eisenhower signed into law an amendment to the Pledge on 15 June 1954 which added the words 'under God. ${ }^{12}$ In an attempt to avoid litigation, Congressional sponsors disclaimed any religious purpose, distinguishing religion as an institution and a belief in the sovereignty of God, agreeing that the modification was 'not an act establishing a religion or one interfering with the "free exercise" of religion. ${ }^{.13}$

\section{Litigation involving the Pledge}

Religious opposition to the Pledge and flag salute, absent the words 'under God,' began as early as 1918. A state court in Ohio rejected the claim of a Mennonite foster father who challenged his being arrested and fined for directing his nine-year-old daughter to neither attend school nor salute the American flag. ${ }^{14}$

As the precursor to a flurry of judicial activity involving the Pledge and flag salute, the Supreme Judicial Court of Massachusetts rejected a First Amendment challenge filed by Jehovah's Witnesses. The court held that as a valid legislative enactment that did not establish a penalty for disobedient students, educators had the right 'to inculcate patriotism and to instill a recognition of the blessings conferred by orderly government.... ${ }^{15}$ The court added that the Pledge and salute did not restrain anyone from worshiping God within the meaning of the First Amendment since they neither relate to nor exact anything in opposition to religion.

\section{The Supreme Court and the Pledge}

Between 1937 and 1939, the Supreme Court refused to hear four challenges to Pledge and/or the flag salute because they lacked substantial federal questions. ${ }^{16}$ At this time, cases from at least three other states failed to reach the Court. ${ }^{17}$

In 1940, the Supreme Court finally accepted a case on the constitutionality of requiring students to salute the flag in Minersville School District v Gobitis (Gobitis). ${ }^{18}$ The Court rejected the claim of Jehovah's Witnesses from Pennsylvania who argued that requiring their children to salute the flag while in school was the equivalent to forcing them to worship an image that violated their right to freedom of religion. The Court reasoned that the students were not free to excuse themselves from participating in the Pledge because it was a rational way to teach patriotism.

Three years later, faced with an ongoing controversy over Gobitis, the Court revisited the issue when Jehovah's Witnesses and others challenged a revised regulation of the West Virginia State Board of Education. According to the regulation, refusal to participate in the flag salute could have been treated as an act of insubordination leading to expulsion from school. As in Gobitis, the Jehovah's Witnesses argued that the law violated their rights to religious freedom. In West Virginia State Board of Education v Barnette (Barnette), ${ }^{19}$ the Court took the unusual step of explicitly reversing Gobitis, finding that educators exceeded constitutional limitations in compelling students to salute the flag. 


\section{Post-Barnette litigation}

The Pledge was not re-litigated again until almost a quarter-century after Barnette. Post-Barnette litigation began with religious objections by students who questioned the inclusion of the words 'under God' based on religion ${ }^{20}$ and free speech, ${ }^{21}$ culminating in suits by teachers who objected to participating in the Pledge. ${ }^{22}$

In Sherman $v$ Community Consolidated School District 21 of Wheeling Township (Sherman), ${ }^{23}$ a case that helped set the stage for Newdow, the Seventh Circuit affirmed that teachers in Illinois could lead the Pledge, including the words 'under God,' as long as children were free not to participate in its daily recitation. The court rejected the claim of a father and son, both of whom were atheists, that the Pledge violated the child's First Amendment right to freedom of religion. The court concluded that the use of the phrase 'under God' in the Pledge was permissible as a form of 'patriotic or ceremonial' expression rather than religious belief.

\section{Elk Grove Unified School District v Newdow}

\section{Background}

Elk Grove began when Michael Newdow, a self-professed atheist and non-custodial father, challenged a board policy, enacted pursuant to state law, which required that teachers begin each school day by having students recite the Pledge. Even though the father conceded that his daughter was not required to join her classmates, he claimed that she was injured by being "compelled to "watch and listen as her state-employed teacher in her state-run school led her classmates in a ritual proclaiming that there is God." "24 Sandra L. Banning, the child's mother, and custodial parent, reported that neither she nor her daughter were troubled by her reciting the Pledge.

A federal trial court, in an unpublished opinion, dismissed the challenge. On appeal, in Newdow $v$ United States Congress (Newdow I), ${ }^{25}$ a divided Ninth Circuit vacated the dismissal in striking down the 1954 statute which added the words 'under God' to the Pledge and the board policy authorizing its daily recitation. Rejecting Congressional disclaimers of a religious purpose in the revised Pledge, the court argued that both the statute and policy violated the Establishment Clause since teachers began each school day by having students recite the words 'under God.' In the face of significant criticism, a day later the court stayed its judgment.

After first refusing to reconsider its judgment, the court not only permitted the father's suit to proceed even though there was a dispute about his standing, ${ }^{26}$ but also rejected motions that Congress ${ }^{27}$ and the child's mother be permitted to intervene. ${ }^{28}$ When an en banc Ninth Circuit, with six members dissenting, ${ }^{29}$ refused to re-examine its earlier opinion, the same initial panel of judges, again by a two-to-one margin, struck the Pledge down, focusing on the narrower ground that 'the school district policy impermissibly coerces a religious act. ${ }^{30}$ The court refused to address the constitutionality of the federal statute that authorized the Pledge even though it rejected the notion that it was a patriotic exercise or a form of civic deism. Further, 
the court glossed over the issue of standing, permitting the non-custodial parent, Newdow, to proceed even though the child's custodial parent (the mother), asserted that her daughter had not suffered any harm. ${ }^{31}$ In light of Sherman, the Supreme Court agreed to hear an appeal in order to resolve the split between the Circuits. ${ }^{32}$

\section{Supreme Court}

\section{Majority opinion}

Writing for the Court, ${ }^{33}$ Justice Stevens limited his relatively brief opinion to a discussion of standing. Acknowledging the Court's reluctance to intervene in domestic relations disputes, Stevens rejected Newdow's challenge to a California state court order which, although amended from its original grant of full custody to the child's mother, still gave her final decision-making power if the two could not agree on what was best for their daughter.

Stevens also refused to grant credence to Newdow's claim that despite Banning's final authority, he had an unrestricted right to inculcate his atheistic beliefs in his daughter free from governmental interference. He explained that nothing in the lower court orders prevented Newdow from discussing his religious, or lack thereof, beliefs, absent a showing that doing so would have harmed his daughter. Stevens concluded that since the state courts had yet to clarify Newdow's standing and custodial status, it would have been inappropriate for the Court to resolve the merits of his claim.

\section{Concurrences}

Chief Justice Rehnquist's concurrence, which was joined in part by Justices O'Connor and Thomas, rejected the Court's position with regard to standing and would have permitted the suit to proceed. ${ }^{34}$ Reasoning that the inclusion of the words 'under God' in the Pledge did not turn it into a religious activity, Rehnquist would have upheld the Pledge on its merits since teachers in no way coerced students who were free not to participate in the Pledge.

Justice O'Connor expounded on her position with regard to governmental endorsement of religion, outlining four bases on which she would have upheld the Pledge as a form of ceremonial deism. ${ }^{35}$ She made four observations regarding the Pledge: in the 50 years since the words 'under God' were added to the Pledge, it has become an almost routine act of patriotism rooted in the daily activities of children that is inseparable from a school context; the words, 'under God,' in the Pledge do not constitute either worship or prayer and, even though some legislators may have acted with religious motivations in amending it to include the words 'under God' in 1954, their intentions should not have decided the Court's inquiry; the words, 'under God,' make no reference to a particular religion; and the religious context in the Pledge is minimal. As such, Justice O'Connor was convinced that a reasonable observer could not have concluded that the Pledge conveyed governmental endorsement of religion. 
Justice Thomas agreed with the Chief Justice that Newdow had standing but wrote a separate concurrence, noting that the father could make no Establishment Clause claim because he had no Free Exercise claim. ${ }^{36}$

\section{Discussion}

For those favoring the continued use of 'under God' in the Pledge, the majority opinion in Elk Grove is a hollow victory. While the Pledge will continue to be used in school systems throughout the US, new litigation by plaintiff-parents with standing will most assuredly arise. Although the Court followed its well-established practice of not resolving a case on constitutional grounds if resolution on a procedural basis is available, future litigation it is not likely to change the facts in a new Pledge challenge before the Court. ${ }^{37}$ When a new case appears before the Court brought by custodial parents, the Court is very likely to address the merits of this case on a set of facts virtually identical to Elk Grove.

In reviewing the Court's holding, it is noteworthy that Justice Kennedy, one of the Court's moderates, along with Justice O'Connor, chose not join any of the concurrences that would have upheld the Pledge. Previously, Kennedy raised questions about the viability of the Pledge as a form of civic deism in County of Allegheny $v$ American Civil Liberties Union Greater Pittsburgh Chapter, ${ }^{38}$ wherein the Court struck down the display of a creche on public property while permitting a display consisting of a menorah, a Christmas tree, and a sign about religious freedom to remain on public property insofar as it concluded that these did not have the unconstitutional effect of advancing religion. Along with Kennedy, four other members of the Court, Justices Stevens, Souter, Ginsburg, and Breyer, all of whom have, in varying degrees, opposed religious activity in public schools and broader public arenas, were unwilling to uphold the constitutionality of the words 'under God' in the Pledge. Kennedy's refusal to join any of the concurrences may not bode well for the future of the Pledge.

The Court's having resolved Elk Grove procedurally, rather than substantively, means that there is neither a clear winner nor a clear loser. Moreover, by delaying an eventual judgment on the merits, the majority effectively defused what might have become a politically charged issue in a presidential election year. Whether that was the Court's intent is unlikely to be known. Yet, at the same time, one must keep in mind that both houses of Congress voted during the summer of 2002, by margins of $94-0$ in the Senate and 416-3, with 11 members voting present, in the House of Representatives, to support the current wording of the Pledge. ${ }^{39}$

\section{Conclusion}

About the most that can be said of Elk Grove is that by failing to address the constitutional question, the Court left the door open to future litigation and perhaps legislation on the wording of the Pledge. Thus, the struggle to find the balance in the relationship between Church and state in America continues. 


\section{Notes}

1124 S. Ct. 2301 (2004).

2 Justice Scalia chose not to participate in the outcome since he criticized the Ninth Circuit's ruling before it reached the High Court. Elk Grove Unified Sch. Dist. v Newdow, 124 S. Ct. 384 (Mem) (2003). See also Mark Walsh, Scalia: Courts go too far on Church State, Education Week, 22 January 2003, p. 22; Houston Chronicle, Justice decries courts removal of God, 13 January 2003, p. 5.

3 Jane Meredith Adams, 'One Nation Divided: Judges Bar Pledge for Kids out West, cite words "under God"', Newsday, 27 June 2003, A 3, 2002 WL 2750909.

4 Paul Wagenseil, History: The Pledge of Allegiance, 27 June 2002. http:/www.foxnews.com/ printer_friendly_story $/ 0,3566,56320,00 . \mathrm{html}$

5 Id. at 3. See also John J. Concannon, 'The Pledge of Allegiance and the First Amendment,' 23 Suffolk U. L. Rev. 1019 (1989).

$6 \quad I d$. at 3.

$7 \quad I d$.

$8 \quad I d$. at $4-5$.

9 H.R. Rep. No. $2047,77^{\text {th }}$ Cong., 2d Sess. 1 (1942); S. Rep. No. $1477,77^{\text {th }}$ Cong., $2 d$ Sess. 1 (1942); codified at 4 U.S.C. $\$ 4$.

10 The original version of the Pledge read 'I pledge allegiance to the Flag of the United States of America, and to the Republic for which it stands, one Nation indivisible, with liberty and justice for all.' $I d$.

11 Maura Dolan, 'Pledge of Allegiance Violates Constitution, Court Declares Law', LA Times, 27 June 2002, at A 1, 2002 WL 2486123; Paul Wagenseil, History: The Pledge of Allegiance. http://www.foxnews.com/printer_friendly_story/0,3566,56320,00.html

124 U.S.C. $\$ 4$ : The Pledge of Allegiance to the Flag: 'I pledge allegiance to the Flag of the United States of America, and to the Republic for which it stands, one Nation under God, indivisible, with liberty and justice for all,'...

13 Brief for the United States in Opposition in Newdow v United States Congress, 2003 WL 22428408, at 4, citing H.R. Rep. No. 83-1693 at 3 (citing Zorach v Clauson, 343 U.S. 306 (1952), S. Rep. No. 83-1287 at 2.

14 Troyer v State, Ohio, 29 Dec. 168, 1918 WL 1176 (Ohio Com. P1. 1918).

15 Nicholls $v$ Mayor of Lynn, 7 N.E.2d 577, 579 (Mass. 1937).

16 Leoles $v$ Landers, 192 S.E. 218 (Ga. 1937), appeal dismissed, 302 U.S. 656 (1937); Hering v State Bd. of Educ., 189 A. 629 (N.J. Sup. Ct. 1937), aff'd, 194 A. 177 (N.J. Err. \& App. 1937), appeal dismissed, 303 U.S. 624 (1938); fohnson v Town of Deerfield, 25 F. Supp. 918 (D. Mass. 1939), aff'd, 306 U.S. 621 (1939), rehearing denied, 307 U.S. 650 (1939); Gabrielli v Knickerbocker 82 P.2d 391 (Cal. 1938), appeal dismissed, cert. denied, 306 U.S. 621 (1939). State ex rel. Bleich v Board of Pub. Instruction for Hillsborough County, 190 So. 815 (Fla. 1939); People ex rel. Fish v Sandstrom, 279 N.Y. 523 ( N.Y. 1939); Reynolds v Rayborn, 116 S.W.2d 836 (Tex. Civ. App. 1938); Shinn v Barrow, 121 S.W.2d 450 (Tex. Civ. App. 1938).

18310 U.S. $586(1940)$.

19319 U.S. 624 (1943).

20 Smith v Denny, 280 F. Supp. 651 (S.D. Cal. 1968) (upholding the Pledge in apparently the first challenge to the inclusion of the words 'under God').

21 Holden v Board of Educ., Elizabeth, 278 A.2d 263 (N.J. 1971) (holding that school officials could not exclude Black Muslim children who refused to recite the Pledge without resolving whether their doing so was religious or political); State v Lundquist, 278 A.2d 263 (Md. 1971) (striking down requirements which would have directed students who objected to saluting the flag to stand while their classmates did so); Banks $v$ Board of Pub. Instruction of Dade County, 314 F. Supp. 285 (S.D. Fla.1970), aff'd, 450 F.2d 1103 (5th Cir.1971) (striking down requirements which would have directed students who objected to saluting the flag to stand 
while their classmates did so); Goetz v Ansell, 477 F.2d 636 (2d Cir. 1973) (finding that even where students had the choice of leaving classrooms or standing silently during the Pledge, officials could not discipline those who objected by remaining quietly seated).

22 Russo v Central Sch. Dist. No. 1, 469 F.2d 623 (2nd Cir. 1972), cert. denied, 411 U.S. 932 (1973) (ruling that a probationary teacher could not be required to join in the recitation ceremony because doing so would have violated her First Amendment right to freedom of expression even if it is expressed in silence); In Opinion of the fustices, (363 N.E.2d 251 (Mass.1977) (declaring that a bill designed to have public school teachers begin the first class of each day by leading students in a recitation of the Pledge would have violated the First Amendment); Palmer $v$ Board of Educ., 603 F.2d 1271 ( $7^{\text {th }}$ Cir. 1979), cert. denied, 444 U.S. 1026 (1980) (affirming, in the only teacher case to reach the merits of a claim, that since a kindergarten teacher in Illinois who was a Jehovah's Witness was not free to disregard the curriculum with regard to patriotic matters, she could be dismissed for refusing to participate in the Pledge, sing patriotic songs, and celebrate specified national holidays).

23758 F. Supp. 1244 (N.D. Ill. 1991), aff'd 980 F.2d 437 (7th Cir.1992), cert. denied, 508 U.S. 950 (1993).

24 Newdow $v$ U.S. Congress (Newdow II), 328 F.3d 466, 483 (9 ${ }^{\text {th }}$ Cir. 2003).

25 Newdow I, 292 F.3d 597 ( $9^{\text {th }}$ Cir. 2002), judgment stayed; amended on denial of rehearing and stayed, 321 F.3d $466\left(9^{\text {th }}\right.$ Cir. 2003), withdrawn from bound volume.

26 Newdow I, 313 F.3d 500 ( $9^{\text {th }}$ Cir. 2002).

27 Newdow I, 313 U.S. F.3d 495 ( $9^{\text {th }}$ Cir. 2002).

28 Newdow I, 313 F.3d 506 (9 $9^{\text {th }}$ Cir. 2002).

29 Newdow v U.S. Congress (Newdow II), supra note 24 at 471.

$30 \quad I d$. at 487.

31 Out From Under God. Newsweek, Aug. 19, 2002, at 12, 2002 WL 7294861.

32 Cert granted sub nom. Elk Grove Unified Sch. Dist. v Newdow, 124 S. Ct. 386 (2003).

33 Justice Stevens' opinion was joined by Justices Kennedy, Souter, Ginsburg, and Breyer. Chief Justice Rehnquist filed an opinion concurring in the judgment, in which Justices O'Conner and Thomas joined as to Part I. Justices O'Connor and Thomas filed separate concurrences. Justice Scalia took no part in the consideration or decision of the case.

34 Newdow, supra note 1 at 2312 (Rehnquist, C.J., concurring).

35 Id. at 2321 (O'Connor, J., concurring).

$36 \quad I d$. at 2327 (Thomas, J. concurring).

37 Although it is on a different aspect of the Pledge, litigation involving the Pledge continues. See The Circle School v Pappert (2004 WL 1852953) (affirming not only that a law from Pennsylvania which required officials in public and non-public schools to notify parents if students refused to participate in the Pledge and/or flag salute was impermissible viewpoint discrimination but also that requiring non-public schools to have students recite the Pledge or national anthem at beginning of each school day violated their First Amendment right to freedom of expressive association).

38492 U.S. 573 (1989).

39 Stephen Dinan (6 March 2003) DeLay threatens to curb courts' jurisdiction: Vents ire over Pledge of Allegiance, Washington Times, A 4, 2003 WL 7707006. 